\title{
Are you a team player or a personal pinner? situating pinterest as part of teachers' online and offline professional learning networks
}

\author{
Lisa Lundgren ${ }^{1 *} \mathbb{D}$, Rachelle Curcio ${ }^{2}$ and Stephanie E. Schroeder ${ }^{3}$
}

\begin{abstract}
Pinterest, a popular social networking site, is used as a resource by educators across all grade levels. We take the perspective that Pinterest acts as a professional learning network (PLN) and interrogate the ways that teachers share resources within online/offline PLNs. Eighty-eight teachers responded to a survey that asked about their social media use as well as their sharing of Pinterest resources with their professional colleagues. Building from the media use typology, we developed the Peer-to-Peer Pinterest Sharing Typology to describe types of sharing, finding that most respondents indicated that they did not share resources, others shared if forced to, and some shared as a way to enhance collegial collaboration. This research expands limited empirical work on both Pinterest as a PLN and on how learning and resources from online PLNs cross into school-based ones. This work will be of interest to those who seek to understand how social media sites play a role in teacher professional learning.
\end{abstract}

Keywords: Professional learning networks, Social media, Teacher professional development, Qualitative research, Social media typology

\section{Introduction}

Educators, in the age of constant communication and instant access to educational resources, are turning to online means such as social media sites to find instructional material. Social media usage by teachers has grown as they seek individualised, on-demand professional development (Prestridge, 2019). One social media site that allows for this is Pinterest, a platform within which people can connect by sharing ideas (i.e., creating posts, called 'pins' and placing them on virtual bulletin boards that are categorised by the user), commenting on other users' pins, repinning pins that appear in the app's feed, and remixing others' ideas to create new pinboards. The majority of users have public pinboards and pins that are

\footnotetext{
*Correspondence: lisa.lundgren@usu.edu

${ }^{1}$ Department of Instructional Technology and Learning Sciences, Utah

State University, Emma Eccles Jones Education Building 953 E $700 \mathrm{~N}$, Logan, UT 84322, USA

Full list of author information is available at the end of the article
}

shared to users' friends, but pins are also algorithmically selected to appear in feeds that share similarities with other users.

Pinterest has been used since its inception by teachers to enhance their lessons and personal learning. As of 2014, Pinterest was identified as a top-five website for educators and not just for personal use (Rayburn, 2014); in 2017, a national survey of teachers in the USA found that 90 per cent of elementary teachers and over 60 per cent of secondary teachers used Pinterest as a resource for educational content (Opfer et al., 2017). According to Hunter and Hall (2017), 'education-related items are the second-most highly searched resource' on Pinterest (p. 634). Recently, researchers positioned Pinterest as a place to develop content for other educators (Robles Moral \& Fernández Díaz, 2021) or as an ideal replacement for in-person professional development (Nixon et al., 2021). Researchers have also interrogated how in-service and pre-service teachers

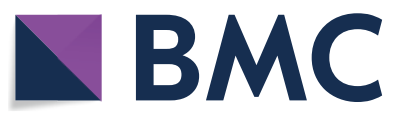

(C) The Author(s) 2021. Open Access This article is licensed under a Creative Commons Attribution 4.0 International License, which permits use, sharing, adaptation, distribution and reproduction in any medium or format, as long as you give appropriate credit to the original author(s) and the source, provide a link to the Creative Commons licence, and indicate if changes were made. The images or other third party material in this article are included in the article's Creative Commons licence, unless indicated otherwise in a credit line to the material. If material is not included in the article's Creative Commons licence and your intended use is not permitted by statutory regulation or exceeds the permitted use, you will need to obtain permission directly from the copyright holder. To view a copy of this licence, visit http://creativecommons.org/licenses/by/4.0/. 
interact with Pinterest content, specifically focusing on the quality of resources that teachers find (Carpenter et al., 2018; Gallagher et al., 2019; Hertel \& WessmanEnzinger, 2017; Hu et al., 2018; Sawyer et al., 2019). Rather than wade into the debate of quality of resources on Pinterest, we see a need to investigate how teachers collaborate with their school-based colleagues through Pinterest and if what teachers encounter on Pinterest gets shared with school-based or 'real-life' colleagues.

Teachers are no longer limited to participating in face-to-face professional development experiences or only sharing resources over lunch or during passing periods. With educational resources easily accessible on social media like Pinterest, Facebook, Twitter, TikTok, and Instagram, we must interrogate the ways that teachers share the knowledge they gain online with their colleagues. Digital learning is happening; thus, educational researchers should interrogate how teachers use the social media ecosystem to find and share resources with colleagues so social media can be effectively integrated into professional learning models. Karimi and colleagues (2020) collected usernames and data in an attempt to quantify collaboration and connections among teachers on Pinterest; we take a qualitative approach to such a notion. Knowing how on online connections translate to offline collaboration can, among other things, help support teacher educators and school-based administration in their quest to best utilise the platform and make good use of collaborative planning time. Furthermore, understanding how such sites are used and shared will allow educational researchers and practitioners to integrate them into research and practice. Our aim in this research is twofold: to explicate how teachers share Pinterest-specific educational resources with their school-based colleagues and to describe the ways that teachers' online and offline sharing proclivities are related to their social media typology. Thus, our research questions are as follows:

1. Do teachers share resources they find on Pinterest with school-based colleagues? If so, how?

2. Does the way teachers interact in online/offline worlds align with their social media typology?

We define school-based colleagues for in-service teachers as colleagues at their local schools and for preservice teachers as their peers in their teacher preparation programmes as well as their colleagues in field placement sites. These definitions help us to see how emerging and in-service teachers bring their online knowledge to the offline spaces they occupy.

\section{Literature review}

\section{Professional learning networks}

With the demand for improved student outcomes in the age of accountability has come a desire to support the growth of teacher collaboration within schools to foster teacher professional development and learning (Moolenaar, 2012; Vangrieken et al., 2015). Standards across professional education organisations, like the US National Council for the Teaching of English (NCTE) and the International Society for Technology in Education (ISTE), for example, encourage educators to 'collaborate with both colleagues and students to improve practice, discover and share resources and ideas, and solve problems' (ISTE Standards for Educators 4, 2017). Professional Learning Networks (PLNs) offer an expansive vision of teacher collaboration, particularly in an increasingly networked and global environment, and one that can account for how teachers' social media use can inform school-based collaborations.

Professional Learning Networks (PLNs) have been defined in multiple ways. Trust (2012), wrote that PLNs are systems of 'interpersonal connections and resources that support informal learning' (p. 133). Flanigan (2011) identified PLNs as 'online communities that allow the sharing of lesson plans, teaching strategies, and student work, as well as collaboration across grade levels and departments' (p. 42). Some scholars have positioned social media sites as online PLNs which facilitate synchronous and asynchronous collaborative engagement, in which people can discuss topics that lead to mutual reflection and understanding (Colwell \& Hutchison, 2017; Cook et al., 2017; Garrison, 2007; Sie et al., 2013). Trust et al. (2016), however, encourage researchers to see that PLNs are 'broader, multifaceted systems that often incorporate multiple communities, networks of practice, and sites that support both on- and off-line learning' (p. 17). PLNs are made up of people, tools, and resources that aid in personalised professional development (Trust et al., 2016) and can exist regardless of temporal and spatial proximity, as ideas and resources can be shared across geographical, temporal, and technological boundaries.

PLNs differ from traditional professional development in that they can be asynchronous, continually responding to the professional learning needs of teachers and school leaders and built from the ground-up (Prestridge, 2020; Trust et al., 2018). For K-12 teachers, PLNs can 'nurture affective, social, cognitive, and identity aspects of their professional growth' (Trust et al., 2016, p. 28). Extant research supports that peer-to-peer collaboration among teachers can enhance student learning (Moolenaar, 2012). Moreover, blending of professional learning between online and face-to-face environments can support enhanced outcomes for teacher learning (Matzat, 
2013). This study, then, explores the ways that teachers shared resources from Pinterest and how such sharing relates to their online (i.e., Pinterest) and offline (i.e., school) learning within their PLNs.

\section{Teachers, social media, and professional learning}

Teacher collaboration in an online PLN often takes place via social media (Trust et al., 2016). A number of empirical articles have recently shown that teachers' use of social media for professional learning and curricular inspiration is widespread (Duncan-Howell, 2010; Huber \& Bates, 2016; Macià \& García, 2016; Sawyer \& Myers, 2018; Sawyer et al., 2019; Trust et al., 2017). Researchers support this professional use, as this 'type of professional development provides an online space for teachers to discuss methods and resources in a quick and efficient manner with a wide-reaching network of educators' (Colwell \& Hutchison, 2017, p. 6). Thus far, researchers have focused largely on how Twitter (Greenhow et al., 2019a, 2019b) and Facebook (Kelly \& Antonio, 2016; Muls et al., 2019; Shelton \& Archambault, 2018) operate as sites of professional learning, yet research on how Pinterest operates as such a space is still nascent. We now share the ways teachers have differently utilised these platforms for the purposes of professional learning.

Twitter is a popular platform with teachers who are seeking online collaboration, community, professional networks (Carpenter \& Krutka, 2014, 2015) and 'just in time' professional development (PD) (Greenhalgh \& Koehler, 2019). Moreover, Fischer et al. (2019) find that Twitter can facilitate features of high-quality professional learning, such as collective participation and duration (Desimone, 2009) by democratising participation and encouraging teacher agency in their learning processes. Indeed, teachers describe their experiences on Twitter positively, indicating that it was a creative and freeing space instead of a PD experience that was done to them (Krutka \& Carpenter, 2016). For emerging teachers, Twitter has been used in a mentoring capacity (Carpenter \& Morrison, 2018; Smith Risser, 2013), as online relationships can supplement insufficient field experiences or connect like-minded teachers.

Identifying its myriad benefits for new teachers, some teacher educators have recommended that teacher candidates be introduced to Twitter early in their undergraduate careers to ensure they 'can access their PLNs to find ideas, feedback, and support' without 'waiting passively for the next PD workshop in hopes it might address their needs' (Carpenter \& Morrison, 2018, p. 28). Because of the dynamic affordances of the platform, teachers have been able to repurpose Twitter towards their needs and use a variety of literacy practices on the site (Greenhalgh et al., 2018). Yet, despite the overwhelming evidence that Twitter supports the cultivation of online PLNs that can offer high-quality professional learning, we see few researchers interrogating how teachers translate their online PLN learning to their face-to-face networks, even though it is known that PLNs traverse both spaces.

Published empirical inquiries into how teachers use Facebook suggest a similar pattern of engagement. Studies have shown that Facebook is a site of collaboration and professional learning where innovative pedagogy can be fostered by sharing teaching strategies and tips (Goodyear et al., 2004; Lantz-Andersson et al., 2017). Facebook brings together already established groups of teachers working on similar projects and facilitates communication with distant peers (Palmquist \& Barnes, 2015) who may not otherwise know one another (Ranieri et al., 2012). Facebook has also been used as an informal learning tool (Cinkara et al. 2017), where new teachers gather resources, collaborate, and develop content and pedagogical content knowledge. Thus, Facebook is considered valuable in pre-service teacher education and across the lifespan of teaching (Manca \& Ranieri, 2016). Importantly, there is evidence that Facebook can enhance the likelihood of face-to-face collaboration of previously disconnected teachers (Ranieri et al., 2012).

Unlike research into Twitter and Facebook, empirical research into teachers' use of Pinterest is nascent (Archambault et al., 2019). A number of scholars and practitioners across the educational spectrum have praised Pinterest's affordances as a space for teachers to find evidence-based practices (Cleaver \& Wood, 2018), connect, network, and share new ideas (Franks \& Krause, 2017), and learn the ins and outs of teaching (Ingram, 2019). Qualitative interview research conducted by Carpenter et al. (2018) support these assertions, as they found that Pinterest serves as a space for networking, collaboration, and the sharing of content.

Researchers have sounded the alarm, however, regarding the quality of what exactly gets shared on Pinterest, finding that pins are often inaccurate, culturally insensitive, and lacking in coherence (Huber \& Bates, 2016; Miller, 2015). Considering the role that PLN collaborations can play in enhancing teacher knowledge of content and pedagogy, we see a need to understand how potentially unsound resources are consumed and digested by teachers not only in an online space, but as they navigate the online and offline networks that support their ongoing learning.

\section{Social media typologies}

As we consider how online spaces provide opportunities for educators to engage in professional learning in person and online, it is useful to parse how people generally engage with such online spaces. One way of analysing 
such engagement is through the creation of social media typologies, which are sometimes called personas or profiles. In general, typologies serve to categorise people and identify conceptual and theoretical features of human behaviour (Johnson \& Kulpa, 2007). Typologies are used to classify social media users based on their patterns of social media use (Brandtzæg, 2010, 2012). Typologies are well used by communications practitioners, especially in the field of marketing, where brands develop internal strategies for defining types of users in order to sell products to them (Rozen et al., 2012). Typologies help us understand the ways different people make use of the online world in order to learn from one another (Lundgren et al., 2019; Aristeidou et al., 2017; Ponciano \& Brasileiro, 2014). We seek here to understand how teachers' online interactions affect their offline interactions, acknowledging the benefits typology research may have to those interested in enhancing PD.

\section{Analytical framework}

We use Brandtzæg's (2010, 2012) media use typology (MUT) as a means for understanding the ways that participants in this study interacted with social media. The MUT, an established analytical framework, was used to define, describe, and delineate participants within this study. Specifically, the MUT, which was created from a meta-analysis of typology literature spanning a five-year period, proposes five user categories defined by their general usage of social media (Table 1).

We used the MUT as an analytical framework to parse participants into categories to better understand how their social media use may relate to their ideas of sharing resources from Pinterest with their offline professional colleagues. In other words, we compare participants' MUT when using social media generally to a newly created typology that we call the Peer-to-Peer Pinterest Sharing Typology that illuminates how they share educational resources found in online social media environments through their online PLNs with their offline, face-to-face PLNs.

\section{Research methods}

\section{Survey design and distribution}

We designed a qualitative study (Merriam \& Tisdell, 2009) involving open- and closed-response survey data. The three-person research team collaboratively designed a 29-question survey; two of the questions from the survey are the focus of this research. In general, survey design was informed by scholarship focused on teachers' use of Pinterest, and specific questions were developed to delve deeper into researchers' suggestions for further research. Following the publication of results from this survey regarding educators' use of Pinterest (Schroeder et al., 2019), we sought to further elaborate on participant responses to survey questions regarding social media use and sharing of Pinterest materials. In the current research, we analysed an open-ended question about sharing Pinterest materials (i.e. 'Do you share your Pinterest boards with peers in your teacher education program? What facilitated that sharing?'). We analyse this question to help determine what resources teachers found and how they shared with colleagues. Additionally, we analysed a close-ended question that asked participants to disclose their personal social media use (i.e. 'Which of the following sentences best describes your personal use of social media?'). We included this question in the study as it allowed us to determine participants' MUT, which directly relates to our research question regarding teachers' online/offline interactions and their social media typology.

Potential participants were able to indicate their interest in participating via responding affirmatively to an informed consent document on the opening page of the survey. Each researcher shared the survey link via select social media and email to personal and professional networks through a method of snowball and convenience

Table 1 MUT and descriptions (from Brandtzæg's (2010, 2012)

\begin{tabular}{lll}
\hline Typology & Frequency of social media use & Statement that describes social media use \\
\hline No Show/NonUser & Almost never & 'I don't use social media' \\
$\begin{array}{l}\text { Newcomer/Sporadics } \\
\text { Onlookers/Lurkers }\end{array}$ & Once a week & 'I don't check social media because I don't find it worthwhile' \\
$\begin{array}{ll}\text { Cliquers/Debaters \& Entertainment Users } \\
\text { Mix \& Minglers/Socialisers }\end{array}$ & Daily & 'I check social media, but I don't post a lot of things' \\
& Multiple times daily & 'I use social media to read news and stories' \\
Sparks/Instrumental \& Advanced Users & Always online & I use social media to exchange information and check in with people.'/'I \\
\end{tabular}

The statements that describe social media use were included as part of the survey given to participants. Participants were allowed to select all descriptions that applied to their use 
sampling (Creswell, 2011). In the current research, we sought to determine teachers' online to offline sharing proclivities and the relationship to social media typologies and report on findings from 88 participants (32 preservice teachers and 56 in-service teachers). We postulate that pre-service teachers are burgeoning members of the teaching community, thus, can be positioned as curriculum makers (Kridel, 2010) in a similar manner to inservice colleagues with additional years of experience. As we were interested in teachers' resource sharing and their online/offline typologies regardless of level of experience, we report the findings in aggregate as opposed to dividing types of teachers.

\section{Participant demographics}

Due to snowball and convenience sampling the vast majority of participants indicated that they taught in one state in the southeastern United States $(n=70)$. In general, participants indicated that they identified as female $(n=86)$; only two participants indicated they were male. Most participants taught elementary school $(n=59)$, followed by those who indicated they taught high school $(n=19)$; few taught middle school $(n=8)$; two participants indicated something else (i.e. teaching pre-service teachers or teaching across grade bands). Participants came from varied teaching experiences, with the majority indicating having five or fewer years teaching experience $(n=60)$ to some having between six- and fifteen-year experience $(n=16)$, and others having 16 or more years of experience $(n=12)$.

\section{Data analysis}

One researcher examined and tallied participant responses to the survey question, 'Which of the following sentences best describes your personal use of social media?' in order to determine teachers' MUT. Then, data analysis followed a method of first and second cycle coding as outlined by Miles et al. (2014) for the survey question 'Do you share your Pinterest boards with peers in your teacher education program? What facilitated that sharing?'. Each researcher accessed participant answers to the survey question then applied first-cycle open codes independently. Following this, codes were compared across researchers to ensure credibility across findings (Tracy, 2010). We then underwent a second round of coding, refining the first-cycle codes and comparing again across researchers (Saldaña, 2013). Then, researchers examined this second round of coding to define typologies based on participants' descriptions of their Pinterest sharing, which we name as the participants' Peer-to-Peer Pinterest Sharing Typology. Each category in the typology represents our final codes which we define and explore in detail in our findings. In a few cases, participant responses were double-coded, as the participant response encapsulated two specific ideas that other participants described. After this, we compared the Pinterest-specific sharing typologies to the MUT to see alignment and misalignment between them.

\section{Results}

In this section, we share findings focused on the identification of survey participants' social media typologies and the potential relationships to the Peer-to-Peer Pinterest Sharing Typology. To organise our findings, first, we share participants' social media MUTs as they relate to Brandtzæg's $(2010,2012)$ media use typology. Next, we describe participant responses regarding whether and how they shared educational content found on Pinterest with their school-based colleagues. The Pinterest-specific findings first focus on how the participants themselves responded to two open-ended survey questions. Then, we move towards interpreting participant responses to highlight their Peer-to-Peer Pinterest Sharing Typologies that account for how participants share online content and learning into offline environments. Lastly, we compare the ways that educators' Peer-to-Peer Pinterest Sharing Typologies complement and contrast with the MUT.

\section{Participants' social media use typologies}

In addition to basic demographic information, we collected data regarding participants' social media typologies (Table 2). These typologies were considered to determine the ways that teachers' social media typologies aligned with or branched from the ways they described

Table 2 Typology frequency of study participants $(n=88)$

\begin{tabular}{ll}
\hline Typology & $\begin{array}{l}\text { Number of } \\
\text { participants } \\
\text { (\%) }\end{array}$ \\
\hline No Show/NonUser & $0(0)$ \\
Newcomer/Sporadics & $0(0)$ \\
Onlookers/Lurkers & $16(18.1)$ \\
Cliquers/Debaters \& Entertainment Users & $4(4.6)$ \\
Mix \& Minglers/Socialisers & $28(31.8)$ \\
Sparks/Instrumental \& Advanced Users* & $29(32.9)$ \\
Mixed Typology & $11(12.5)$
\end{tabular}

As the social media typology was tiered, Sparks/Instrumental/Advanced Users encompassed those who only selected the phrase'I don't want to miss anything, so I'm always checking my social media.' $(n=9)$ as well as those who selected all phrases associated with both Cliquers/Debaters \& Entertainment Users and Mix \& Minglers/Socialisers $(n=20)$

${ }^{a}$ As participants were allowed to select multiple descriptions of their social media use, this led to the creation of the mixed typology category (e.g. participants who selected phrases affiliated with the typology Onlookers/ Lurkers AND phrases associated with Mix \& Minglers/Socialisers) 
sharing Pinterest-specific educational resources with colleagues in their local, face-to-face environment. No teachers indicated that they interacted with social media in ways that No Show/NonUsers or Newcomer/Sporadics would. There were very few Cliquers/Debaters \& Entertainment Users $(n=4)$ as well as few Onlooker/ Lurkers $(n=16)$. The majority of participants were classified as Sparks/Instrumental Users $(n=29)$ or Mix \& Minglers/Socialisers $(n=28)$. Eleven participants had a mixed social media typology, meaning their social media use crossed bounds of the original tiered typology.

\section{Peer-to-peer Pinterest sharing typologies}

We found that $67 \%(n=59)$ of participants did not share items they curated on Pinterest with peers. Thirty-three per cent of participants claimed they shared resources and ideas curated on Pinterest $(n=29)$ in order to provide inspiration to peers, gain ideas from colleagues, and as a tool to prepare for lesson planning. Going beyond these raw numbers, we identified five main Peer-to-Peer Pinterest Sharing Typologies with sub-typologies embedded within (Table 3). Peer-to-Peer Pinterest sharing typologies include: (1) The Team Player (sub-typologies: Virtual Team Player and Face-to-Face Team Player), (2) The Constrained Colleague, (3) The Conscripted Colleague, (4) The Archivist (sub-typologies: Limited to
Friends, Open Curator), and (5) The Personal Pinner (sub-typologies: Strictly Personal Pinner, The Filer).

\section{The team player}

The Team Player actively shared items found on Pinterest with offline teammates and colleagues. We characterised Team Players by their commitment to collaborationPinterest boards were not solely for their own private use, nor were they merely open to the public. When elaborating on what facilitated their sharing, Team Players indicated they shared pins with co-teachers, para-professionals, teammates, cohort members, and grade-level teams. Specifically, these individuals discussed how sharing pins with teammates added to the planning process. Overall, these participants viewed Pinterest as an extension of their collaborative experiences with colleagues, teammates, and peers that enabled them to enhance curriculum and learning through intentional sharing of resources and ideas. As one participant shared:

I do share these boards with other pre-service teachers. Most often during conversations or when my fellow peers are in need of inspiration. I share my Pinterest boards with them or recommend that they use the app to find ideas that work best for their classroom.

Table 3 Peer-to-peer Pinterest sharing typologies $(n=91)$

\begin{tabular}{|c|c|c|c|c|}
\hline Typology sub-typologies & Number & $\%$ & Typology description & Exemplar quote from each typology \\
\hline The Team Player & 11 & 12.1 & $\begin{array}{l}\text { Active sharing of Pinterest items with teammates } \\
\text { and colleagues }\end{array}$ & $\begin{array}{l}\text { Yes [I share]. I am friends with a few teachers on my } \\
\text { grade-level team and we share pins and ideas that } \\
\text { benefit the both of us because we teach the same } \\
\text { curriculum }\end{array}$ \\
\hline Virtual Team Player & 4 & 4.4 & $\begin{array}{l}\text { Intentional virtual sharing with offline, school- } \\
\text { based colleagues }\end{array}$ & $\begin{array}{l}\text { We send pins to each other all the time! This makes } \\
\text { it easier than trying to explain the pin later }\end{array}$ \\
\hline Face-to-Face Team Player & 9 & 9.9 & $\begin{array}{l}\text { Intentional sharing of Pinterest items in face-to- } \\
\text { face environments, such as team meetings }\end{array}$ & We all share ideas in team meetings \\
\hline The Constrained Colleague & 7 & 7.7 & $\begin{array}{l}\text { Willing to share Pinterest items but unable to } \\
\text { because of extenuating circumstances }\end{array}$ & $\begin{array}{l}\text { No [I do not share]. My administration considers it } \\
\text { 'social media'. }\end{array}$ \\
\hline The Conscripted Colleague & 4 & 4.4 & $\begin{array}{l}\text { Commissioned to share with others through a } \\
\text { course assignment or administrative request }\end{array}$ & $\begin{array}{l}\text { Yes, once to share the technology websites as our } \\
\text { department's Tech Lead }\end{array}$ \\
\hline The Archivist & & & $\begin{array}{l}\text { Uses Pinterest primarily for themselves, but } \\
\text { acknowledges the openness of the medium }\end{array}$ & \\
\hline Limited to Friends & 4 & 4.4 & $\begin{array}{l}\text { Used Pinterest to create personal, private boards } \\
\text { that could only be seen by themselves and their } \\
\text { friends }\end{array}$ & $\begin{array}{l}\text { I don't share them [my boards and pins] specifically. } \\
\text { However, I know that other teachers follow my } \\
\text { Pinterest }\end{array}$ \\
\hline Open Curator & 9 & 9.9 & $\begin{array}{l}\text { Viewed Pinterest as a public domain in which } \\
\text { sharing could occur, but it was not their primary } \\
\text { purpose for use }\end{array}$ & $\begin{array}{l}\text { My education pinboards are public and can be } \\
\text { viewed by others }\end{array}$ \\
\hline The Personal Pinner & & & Uses Pinterest for their own purposes & \\
\hline Strictly Personal & 38 & 41.8 & $\begin{array}{l}\text { Explicit statement of not sharing resources culti- } \\
\text { vated on Pinterest }\end{array}$ & $\begin{array}{l}\text { No [l don't share]. I just use them to categorise my } \\
\text { own ideas }\end{array}$ \\
\hline The Filer & 5 & 5.5 & Pinterest was used as a place to categorise ideas & $\begin{array}{l}\text { [l use Pinterest] as a dumping ground to look back } \\
\text { at when in need of some ideas }\end{array}$ \\
\hline
\end{tabular}


Twenty-four participant responses were coded as 'Team Player.' Within these responses, 11 communicated that they shared their boards through general statements, such as one participant who wrote, 'sharing is caring.' These individuals were not specific regarding their mechanisms for sharing, but they explicitly stated they shared pinned Pinterest resources with their offline PLN of coteachers, teammates, colleagues, and friends. Conversely, other responses coded as 'Team Player' provided specific information related to where and how they shared Pinterest resources with colleagues. Due to the variance in these Team Player's sharing styles, we developed two subtypologies in addition to the main Team Player typology $(n=11)$ : The Virtual Team Player $(n=4)$ and The Faceto-Face Team Player $(n=9)$.

The Virtual Team Player. The Virtual Team Player $(n=4)$ was characterised by their intentional virtual sharing with offline, school-based colleagues. These individuals strategically 'shared boards with all Pinterest members at school,' sent 'pins to other teachers on Pinterest,' and shared 'specific pins to teachers through email.' One response illustrated the Virtual Team Player when stating, 'We send pins to each other all the time! This makes it easier than trying to explain the pin later.'

The Face-to-Face Team Player. When explaining their methods for sharing, the Face-to-Face Team Player $(n=9)$ described sharing materials found on Pinterest during team meetings, planning sessions, and during lunch. Whether they engaged in common team planning or planning for co-teaching, Pinterest pins became a source of discussion. Some participants directly shared Pinterest boards with teammates 'before we come together to discuss each one,' and others emailed them to later 'discuss findings over lunch.' These individuals cultivated items on Pinterest and used pins to facilitate face-to-face conversations. Specifically, one participant noted that her team has a shared Pinterest board that they use as a source of discussion during team planning. Whether sharing pins during conversations to inspire peers or identifying items 'we think each other will like,' the Face-to-Face Team Player was a collaborative Pinterest user who intentionally connected their online PLN to their offline PLN.

\section{The constrained colleague}

The Constrained Colleague $(n=7)$ was willing to share but unable to because of extenuating circumstances. For some, these circumstances included a hostile school environment and school-based administrative constraints. One participant shared their administrator did not support Pinterest, as they 'consider[ed] it social media.' Other participants had a sense of selfconstraint, as they thought they did not have enough of either resources or experiences to share. These individuals 'wouldn't mind sharing' and 'probably will do so in the future,' yet they indicated that they had not shared because they 'have not curated much information.' Overall, these individuals expressed an interest in sharing; yet, due to a lack of information or collaborative school-based support they communicated a sense of constraint.

\section{The conscripted colleague}

The Conscripted Colleague $(n=4)$ typology consisted of those who were commissioned to share with others through a course assignment or administrative request. These individuals explicitly communicated that they shared items cultivated on Pinterest because they were asked either explicitly through faculty presentations (if an in-service teacher) or implicitly through course assignments (if a pre-service teacher).

\section{The archivist}

The Archivist consisted of individuals who created boards and primarily pinned for themselves; however, they acknowledged that due to the openness of the medium, their school-based colleagues could connect with them virtually. Some archivists claimed that they limited their board to friends or followers only, while others acknowledged that anyone could see their boards. We see archivists as those who collected, curated, and sorted, but who shared only with those who made an effort to visit the archive. Two Archivist sub-typologies emerged: 1) Limited to Friends and 2) Open Curator.

Limited to Friends. Whereas Pinterest is primarily used for the creation of personal boards, these Archivists $(n=4)$ expressed a willingness to share curated pins with followers. They discussed following friends on Pinterest and noted that boards are 'open to my followers.' Thus, friends that follow this Archivist can access their pins.

Open Curator. The Open Curator $(n=9)$ viewed Pinterest boards as public domain, indicating that their boards are public. They recognised that other teachers could openly access their pins and explained that their 'education pinboards are public and can be viewed by others.' Thus, if others wanted to access their Pinterest boards, they could do so publicly or as a follower. Whereas these individuals expressed that they do not share items cultivated on Pinterest, at the same time they recognised that their Pinterest boards are public so 'anybody has access to it.' Thus, the Open Curators were characterised by viewing sharing as something that could organically occur within the online space of Pinterest, as opposed to their offline PLN. 


\section{The personal pinner}

The Personal Pinner pinned for their own purposes and did not describe their engagement with Pinterest as collaborative. These individuals did not describe any means for actively sharing their pins nor did they acknowledge that boards may be public to other users. However, within the Personal Pinners two sub-typologies evolved: (1) Strictly Personal Pinner and (2) The Filers.

Strictly Personal Pinner. Strictly Personal Pinners $(n=38)$ explicitly stated they did not share resources cultivated on Pinterest. These individuals used Pinterest and cultivated boards, but they claimed they did not share.

The Filer. For these individuals $(n=5)$, Pinterest is a space to categorise ideas, or a 'dumping ground to look back at when in need of some ideas.' The Filers used Pinterest as a personal curation tool that does not cross over into school-based collaborations. However, several participants stated they 'wouldn't mind' sharing pinned resources if asked in the future.

\section{Describing the relationship between educators' social} media and their peer-to-peer pinterest sharing typologies With participants' MUT and Peer-to-Peer Pinterest Sharing Typologies accounted for, we sought to explore the connections between them (Fig. 1). We first discuss incidents where there was perceived misalignment between the two typologies, then describe occurrences of alignment.

In terms of misalignment, we saw that regardless of social media typology category, the Peer-to-Peer Pinterest Sharing Typology of Personal Pinner was highly represented. A specific incidence of this is the way in which the typology of Personal Pinner was highly represented in the social media typology categories of Sparks/Instrumental \& Advanced Users as well as Mix and Mingler.

The majority of participants who had originally been identified as Sparks/Instrumental \& Advanced Users were categorised as Personal Pinners in the emergent peer-to-peer Pinterest sharing typology. Sparks/Instrumental \& Advanced Users were those who had indicated sophisticated social media use, including being on social media constantly, and using it to pursue multiple avenues, including connecting with others, reading the news, and generally being 'in the loop.' This is in contrast to the way that Personal Pinners engage with Pinterest, as they tended to use the site for personal filing of ideas rather than to connect and share with others.

The same aspect of misalignment occurred when examining how many Mix and Minglers were categorised as Personal Pinners within the Peer-to-Peer Pinterest

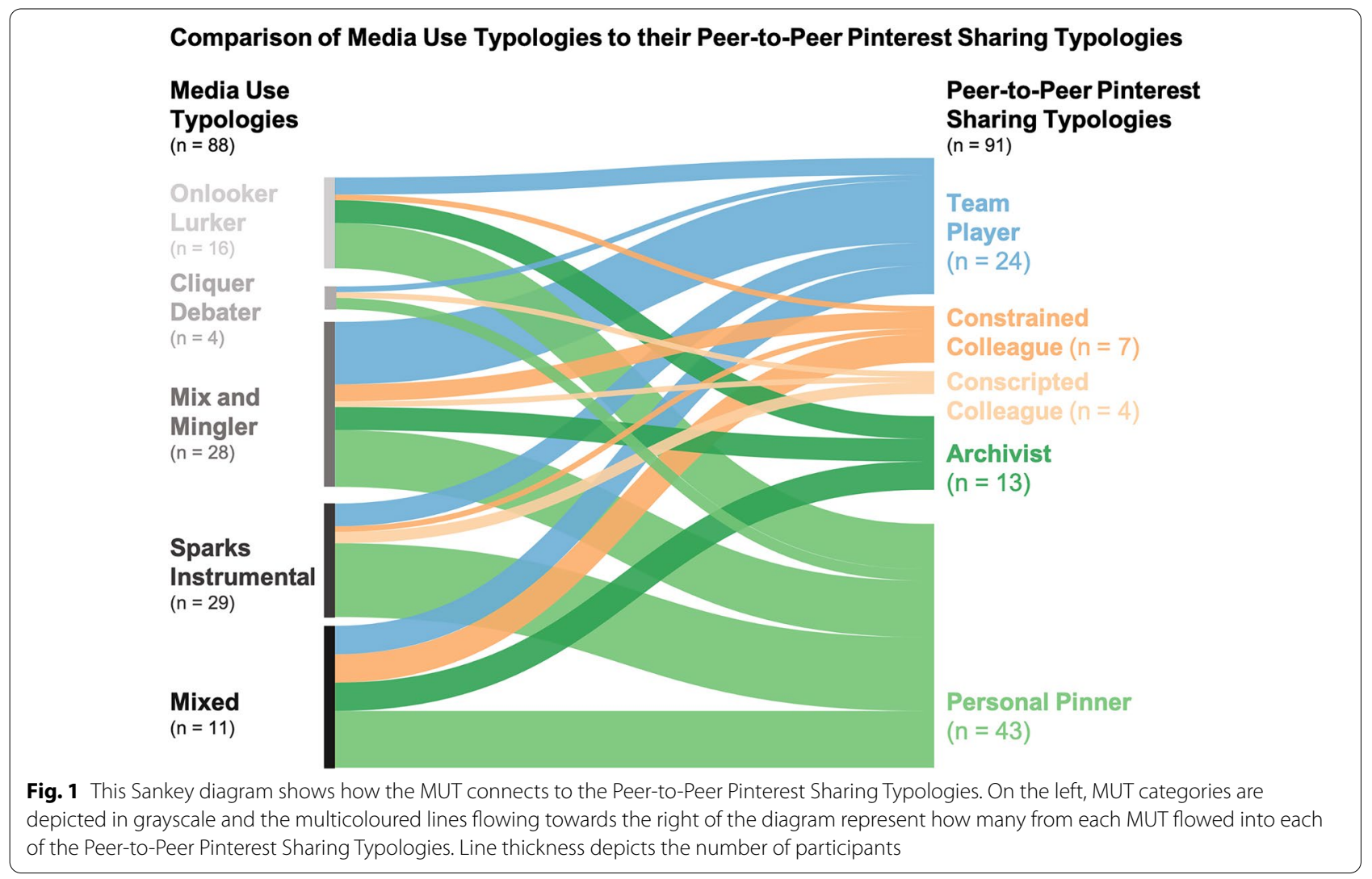


Sharing Typology. Within the MUT, Mix and Minglers were those who indicated that they used social media to exchange information with others and post about their day. Yet, when describing their use of Pinterest, these participants were mostly uninterested in sharing Pinterest resources with colleagues.

In terms of the MUT and Peer-to-Peer Pinterest Sharing Typologies alignment, two examples are worth noting: the connection between Onlookers/Lurkers and Personal Pinners and between Mix \& Minglers/Socialisers and Team Players. Within the typology of Onlookers/ Lurkers, described as those who check social media but rarely post, was a high representation of the Peer-to-Peer Pinterest Sharing Typology of Personal Pinners. We see these typologies as aligned, as using Pinterest as a means to file ideas or store ideas for themselves is well aligned with the conceptualisation of checking social media and posting with less frequency. This means that in some cases, teachers who were looking for resources on Pinterest were supported by the platform, where they could use Pinterest for their own purposes without needing to interact with others in either their online or offline PLN.

MUT and Peer-to-Peer Pinterest Sharing Typology alignment also occurred within the intersection of Mix \& Minglers/Socialisers and Team Players. In the social media typology, Mix \& Minglers/Socialisers were those who used social media to exchange information, check in with people, and post about their daily experiences. In the Peer-to-Peer Pinterest Sharing Typology, Team Players were those who actively shared Pinterest items with teammates and colleagues. Thus, for these participants, their way of being within their online PLN related directly to the way that they share with school-based PLN.

\section{Discussion}

Our aims in this research have been to explicate how teachers share Pinterest-specific educational resources with their school-based colleagues and to describe the ways that teachers' online and offline sharing proclivities are related to their social media typologies. While the majority of research around teachers and their PLNs has focused solely on the online component of a PLN, this research has sought to understand what happens to networked collaboration as teachers move between the online and offline spaces they inhabit. While research has uncovered that sites like Twitter, Facebook, and Pinterest are popular sites for teachers that have been found to foster innovation and collegiality within the specific platforms, we argue that previous research does not go far enough into interrogating how learning on social media sites that constitute teachers' PLNs translate to schoolbased collaborations.
We made use of Brandtzæg's (2010, 2012) MUT to categorise study participants, which led to the creation of our Peer-to-Peer Pinterest Sharing Typology as the MUT did not capture the nuances of Pinterest-based networked collaboration by teachers. Our subsequent analysis revealed alignments as well as misalignments between the MUT and the Peer-to-Peer Pinterest Sharing Typology. Categorising social media users in this way is prevalent in communications research. Indeed, communications researchers have found that such categorisation can reveal trends in use as well as predict how users might gain social capital (Naseri, 2017). Although communications researchers have embraced the categorisation of social media users, few researchers have examined this concept within educational contexts. Such research is limited to informal learning spaces such as social media sites and is discipline-specific, focusing on the geosciences (Lundgren et al., 2018; Schroeder et al., 2019).

As educational researchers, we must consider the implications of using frameworks that have been designed for non-educative contexts, since these rarely capture the nuance of educational work and use of social media sites. Future researchers could explore how social media use typologies within educational research could augment PD experiences. Currently, such PD experiences do not account for teachers' use of social media platforms for content development and peer support, although it is clear that social media as a means of PD can augment teachers' self-efficacy as well as act as collaborative spaces (Carpenter \& Green, 2018; Carpenter et al., 2020a). Applying social media typologies in PD settings and accounting for the connections between online and offline collaboration could allow for such PD activities to better account for what works, for whom, and under what conditions.

Our findings show that there are varying methods of sharing between teachers' online and offline PLNs, some of which relate to how teachers describe their use of other social media. Acknowledging that research into how teachers share and engage on single platforms can only illuminate a sliver of their engagement in professional learning, understanding more about how teachers bring knowledge and resources gained from online PLNs to their face-to-face environments provides more insight into the myriad ways teachers collaborate or choose not to collaborate. This matters, as collaboration is perceived as an essential skill for educators-it is often measured through professionalism requirements in teacher education programmes (Creasy, 2015), and often included in externally mandated standards for educators.

For example, the ISTE standards for educators include a standard called 'Collaborator' which emphasises the 
ability to collaborate with colleagues during dedicated planning time, co-learn with students, and use technology-based collaborative tools. An additional ISTE standard tasks educators with modelling 'the identification, exploration, evaluation, curation and adoption of new digital resources and tools for learning' (ISTE, Standard 2c). Within this study, approximately a quarter of survey responses were classified under the Peer-to-Peer Pinterest Sharing Typologies category of 'Team Player', whose responses align with the ISTE standard: they could identify, explore, evaluate, and curate online resources in addition to sharing these resources with colleagues. While literature about professional learning on Pinterest suggests that it is a site of collaboration and networking (Archambault et al., 2019; Franks \& Krause, 2017), these affordances do not necessarily translate to face-toface collaboration and learning with school-based peers, meaning that there is a potential loss of collaboration and innovation as teachers shift between online and offline spaces.

With the great majority of teachers in this study emphasising their hesitancy and/or unwillingness to share Pinterest-based resources with their school-based peers, we encourage pre-service and in-service teacher PD efforts to continue to infuse ways to authentically support the sharing of online resources to normalise the practice of sharing, discussing, and evaluating resources. As Nochumson (2019) discussed, supporting teachers' collaboration on ideas found in online spaces may lead to more critically informed decision making regarding the teaching practices carried into offline spaces and ultimately the classroom. Those who caution against using Pinterest may see Pinterest's lack of crossover into school-based or face-to-face PLNs as positive. To some, the less Pinterest is shared, the better. However, we see the lack of collaboration with local colleagues as problematic. Without thoughtful engagement with those in their hyper-local context, we question whether teachers are able to address a documented lack of cultural and racial diversity in the pins (Chang et al., 2014) or even address potential factual inaccuracies. Bringing together the multiple perspectives of members of school-based PLNs could help to minimise the use of problematic materials from Pinterest. Research has also shown that teachers' pins have an impact on student achievement, with more pins focused on memorisation having a negative impact on student learning (Knake et al., 2021). We posit that sharing pins in the school-based setting can potentially support a cross-flow of pinned material that might interrupt pinning patterns that have deleterious impacts on student learning.

Thus, on a practical level, teacher educators and those working in teacher PD should consider structures for ensuring boundaries of PLNs are fluid or acknowledged. Carpenter and Morrison (2018) describe how to foster Twitter-specific PD, emphasising how the inclusion of Twitter and Instagram in teacher education courses can bridge the gap of theory and practice for pre-service teachers (Carpenter et al., 2020a, 2020b). We recommend that teacher educators and PD leaders explore how structures for collaboration are designed and developed for other social media platforms as well as between social media platforms and face-to-face professional learning networks. Cultivating habits of collaboration online, offline, and between online and offline spaces should begin in teacher education courses and continue through PD opportunities. Something as simple as connecting face-to-face colleagues on social media platforms like Pinterest could be the push individuals need to collaborate. On the other hand, many teachers did share resources across online and offline spaces. Teacher educators and PD leaders can integrate this type of sharing in face-to-face learning communities and when designing PD experiences as a way to formally support collaboration across online and offline spaces.

\section{Conclusion}

Within this study, we investigated the ways that teachers shared resources they found on Pinterest with their school-based colleagues. We also sought to understand how the ways that teachers interact in online/offline worlds aligned with their social media typologies. While Pinterest allowed for some participants to connect, especially those who indicated that they already used social media with the aim of connecting, when transferring learning or a sense of community to face-to-face environments, collaboration is limited. We believe this study has laid groundwork in understanding how Pinterest operates within the broader PLNs teachers take part in. With this interconnected, online/offline conception of PLNs in mind, Trust et al. (2016) recommend researchers 'be mindful about the limitations of focusing on single aspects of PLNs and potentially losing sight of the forest for the trees' (p. 28). In this study, we take their advice by positioning Pinterest as one tool in educators' interconnected PLNs, asking how this one online tool that connects teachers at a global-level transfers to the hyperlocal, school-based PLNs in which teachers participate.

\section{Abbreviations}

ISTE: International Society for Technology in Education; MUT: Media Use Typology; NCTE: National Council for the Teaching of English; PLN: Professional Learning Network; PD: Professional Development. 


\section{Acknowledgements}

The authors would like to thank the study participants for their participation as well as the editors and reviewers who provided feedback on this manuscript.

\section{Authors' contributions}

LML: conceptualization, data curation, formal analysis, investigation, methodology, project administration, software, visualization, writing-original draft preparation, writing-review \& editing. RC: conceptualization, formal analysis, investigation, methodology, writing-original draft preparation, writing-review \& editing. SES: conceptualization, formal analysis, investigation, methodology, writing-original draft preparation, writing-review \& editing. All authors read and approved the final manuscript.

\section{Funding}

This manuscript was not supported by external funding

\section{Availability of data and materials}

The datasets used and/or analysed during the current study are available from the corresponding author on reasonable request.

\section{Declarations}

\section{Competing interests}

The authors declare no competing interests.

\section{Author details}

'Department of Instructional Technology and Learning Sciences, Utah State University, Emma Eccles Jones Education Building 953 E 700 N, Logan, UT 84322, USA. ${ }^{2}$ Instruction and Teacher Education, University of South Carolina, Columbia, USA. ${ }^{3}$ Curriculum and Instruction, Pennsylvania State University, State College, USA.

Received: 14 June 2021 Accepted: 15 September 2021

Published online: 26 September 2021

\section{References}

Archambault, L., Hale, A., Shelton, C. \& Puga, S. (2019). Inspiration by way of Pinterest: Tracking educators' use of social media to locate and share classroom resources. In K. Graziano (Ed.), Proceedings of Society for Information Technology \& Teacher Education International Conference (pp. 990-994). Las Vegas, NV, United States: Association for the Advancement of Computing in Education (AACE).

Aristeidou, M., Scanlon, E., \& Sharples, M. (2017). Profiles of engagement in online communities of citizen science participation. Computers in Human Behavior, 74(September), 246-256. https://doi.org/10.1016/j.chb.2017.04. 044.

Brandtzæg, P. B. (2010). Towards a unified media-user typology (MUT): A metaanalysis and review of the research literature on media-user typologies. Computers in Human Behavior, 26(5), 940-956. https://doi.org/10.1016/j. chb.2010.02.008.

Brandtzæg, P. B. (2012). Social networking sites: Their users and social implications-A longitudinal study. Journal of Computer-Mediated Communication, 17(4), 467-488. https://doi.org/10.1111/j.1083-6101.2012.01580.x.

Carpenter, J., Cassaday, A. \& Monti, S. (2018). Exploring How and Why Educators Use Pinterest. In E. Langran \& J. Borup (Eds.), Proceedings of Society for Information Technology \& Teacher Education International Conference (pp. 2222-2229). Washington, D.C., United States: Association for the Advancement of Computing in Education (AACE).

Carpenter, J. P., \& Green, T. D. (2018). Self-directed professional learning and educator self-efficacy: The case of Voxer. In C. Hodges (Ed.), Self-efficacy in instructional technology contexts (pp. 163-181). Berlin: Springer. https:// doi.org/10.1007/978-3-319-99858-9_10.

Carpenter, J. P., \& Krutka, D. G. (2014). How and why educators use Twitter: A survey of the field. Journal of Research on Technology in Education, 46(4), 414-434. https://doi.org/10.1080/15391523.2014.925701.

Carpenter, J. P., \& Krutka, D. G. (2015). Engagement through microblogging: Educator professional development via Twitter. Professional Development in Education, 41(4), 707-728. https://doi.org/10.1080/19415257.2014. 939294.

Carpenter, J. P., \& Morrison, S. A. (2018). Enhancing teacher education... with Twitter? Phi Delta Kappan, 100(1), 25-28.

Carpenter, J. P., Morrison, S., Craft, M., \& Lee, M. (2020b). How and why are teachers using Instagram? Teaching and Teacher Education, 96, 103-149. https://doi.org/10.1016/j.tate.2020.103149.

Carpenter, J., Tani, T., Morrison, S., \& Keane, J. (2020a). Exploring the landscape of educator professional activity on Twitter: An analysis of 16 educationrelated Twitter hashtags. Professional Development in Education. https:// doi.org/10.1080/19415257.2020.1752287.

Chang, S., Kumar, V., Gilbert, E., \& Terveen, L. G. (2014). Specialization, homophily, and gender in a social curation site: Findings from Pinterest. In: Proceedings of the 17th ACM Conference on Computer Supported Cooperative Work \& Social Computing - CSCW'14 (pp. 674-686). New York, New York, USA: ACM Press. https://doi.org/10.1145/2531602.2531660.

Cinkara, E., \& Arslan, F. Y. (2017). Content analysis of a Facebook group as a form of mentoring for EFL teachers. English Language Teaching, 10(3), 40. https://doi.org/10.5539/elt.v10n3p40.

Cleaver, S. L., \& Wood, C. L. (2018). Using Pinterest to find and share evidencebased practices. Intervention in School and Clinic, 54(2), 111-117. https:// doi.org/10.1177/1053451218765212.

Colwell, J., \& Hutchison, A. C. (2017). Considering a Twitter-based professional learning network in literacy education. Literacy Research and Instruction, 57(1), 1-21. https://doi.org/10.1080/19388071.2017.1370749.

Cook, R. J., Jones-Bromenshenkel, M., Huisinga, M. S., \& Mullins, F. (2017). Online professional learning networks. Journal of Special Education Technology, 32(2), 109-118. https://doi.org/10.1177/0162643417696930.

Creasy, K. L. (2015). Defining professionalism in teacher education programs. Journal of Education \& Social Policy, 2(2), 23-25.

Creswell, J. (2011). Educational research: Planning, conducting, and evaluating quantitative and qualitative research (4th ed.). Pearson.

Desimone, L. M. (2009). Improving impact studies of teachers' professional development: Toward better conceptualizations and measures. Educational Researcher, 38(3), 181-199. https://doi.org/10.3102/0013189X08 331140.

Duncan-Howell, J. (2010). Teachers making connections: Online communities as a source of professional learning. British Journal of Educational Technology, 41(2), 324-340. https://doi.org/10.1111/j.1467-8535.2009.00953.x.

Fischer, C., Fishman, B., \& Schoenebeck, S. Y. (2019). New contexts for professional learning: Analyzing high school science teachers' engagement on Twitter. AERA Open, 5(4), 233285841989425. https://doi.org/10.1177/ 2332858419894252.

Flanigan, R. (2011). Professional learning networks taking off. Education Week.

Franks, H., \& Krause, J. M. (2017). Winning with pinning: Enhancing health and physical education with Pinterest. Journal of Physical Education, Recreation, \&Dance, 88(5), 15-19. https://doi.org/10.1080/07303084.2017.1280440.

Gallagher, J., Swalwell, K. M., \& Bellows, E. M. (2019).'Pinning' with pause: Supporting teachers' critical consumption on sites of curriculum sharing. Social Education, 83(4), 217-224.

Garrison, D. (2007). Online community of inquiry review: Social, cognitive, and teaching presence issues. Journal of Asynchronous Learning Networks, 11 , $61-72$.

Goodyear, P., Banks, S., Hodgson, V., McConnell, D. (2004). Research on networked learning: An overview. In Advances in research on networked learning, 1-9. Computer-Supported Collaborative Learning Series. Springer Netherlands.

Greenhalgh, S. P., \& Koehler, M. J. (2019). 28 days later: Twitter hashtags as 'just in time' teacher professional development. TechTrends, 63(4), 499-499. https://doi.org/10.1007/s11528-016-0142-4.

Greenhalgh, S. P., Staudt Willet, K. B., Rosenberg, J. M., \& Koehler, M. J. (2018). Tweet, and we shall find: Using digital methods to locate participants in educational hashtags. TechTrends, 62(5), 501-508. https://doi.org/10.1007/ s11528-018-0313-6.

Greenhow, C., Galvin, S. M., \& Staudt Willet, K. B. (2019a). What should be the role of social media in education? Policy Insights from the Behavioral and Brain Sciences, 6(2), 178-185. https://doi.org/10.1177/2372732219865290.

Greenhow, C., Gleason, B., \& Staudt Willet, K. B. (2019b). Social scholarship revisited: Changing scholarly practices in the age of social media. British Journal of Educational Technology, 50(3), 987-1004. https://doi.org/10. 1111/bjet.12772. 
Hertel, J., \&Wessman-Enzinger, N. (2017). Examining Pinterest as a curriculum resource for negative integers: An initial investigation. Education Sciences, 7(2), 45. https://doi.org/10.3390/educsci7020045.

Hu, S., Torphy, K. T., Opperman, A., Jansen, K., \& Lo, Y.-J. (2018). What do teachers share within socialized knowledge communities: A case of Pinterest. Journal of Professional Capital and Community, 3(2), 97-122. https://doi. org/10.1108/JPCC-11-2017-0025.

Huber, R., \& Bates, C. C. (2016). Are you (p)interested in 21 st century teaching and learning? Young Children, 71(3), 25-30.

Hunter, L. J., \& Hall, C. M. (2017). A survey of K-12 teachers' utilization of social networks as a professional resource. Education and Information Technologies, 23(2), 1-26. https://doi.org/10.1007/s10639-017-9627-9.

Ingram, C. (2019). The edupreneur frontier: Creating a new system of curriculum and professional development for teachers. Art Education, 72(5), 14-18. https://doi.org/10.1080/00043125.2019.1621629.

ISTE Standards for Educators (2017). International Society for Technology in Education. https://www.iste.org/standards/for-educators.

Johnson, G. M., \& Kulpa, A. (2007). Dimensions of online behavior: Toward a user typology. Cyberpsychology \& Behavior: THe Impact of the Internet, Multimedia and Virtual Reality on Behavior and Society, 10(6), 773-779. https:// doi.org/10.1089/cpb.2007.0043.

Karimi, H., Torphy, K. T., Derr, T., Frank, K. A. \& Tang, J. (2020, December 8-11) Understanding and promoting teacher connections in online social media: $A$ case study on Pinterest [Paper presentation]. 2020 IEEE International Conference on Teaching, Assessment, and Learning for Engineering (TALE), Takamatsu, Japan. https://doi.org/10.1109/TALE48869.2020.9368377.

Kelly, N., \& Antonio, A. (2016). Teacher peer support in social network sites. Teaching and Teacher Education, 56(May), 138-149. https://doi.org/10. 1016/j.tate.2016.02.007.

Knake, K. T., Chen, Z., Yang, X., \& Tait, J. (2021). Pinterest curation and student achievement: The effects of elementary mathematics resources on students' learning over time. The Elementary School Journal. https://doi. org/10.1086/715480.

Kridel, C. (2010). Teachers as curriculum makers. In Encyclopedia of curriculum studies (Vol. 1, pp. 868-869). SAGE Publicataions, Inc. https://doi.org/10. 4135/9781412958806.n459.

Krutka, D. G., \& Carpenter, J. P. (2016). Participatory learning through social media: How and why social studies educators use Twitter. Contemporary Issues in Technology and Teacher Education, 16(1), 38-59.

Lantz-Andersson, A., Peterson, L., Hillman, T., Lundin, M., \& Rensfeldt, A. B. (2017). Sharing repertoires in a teacher professional Facebook group. Learning, Culture and Social Interaction, 15(December), 44-55. https://doi. org/10.1016/j.lcsi.2017.07.001.

Lundgren, L., Crippen, K. J., Gardner, E. E., Perez, V. J., \& Leder, R. M. (2018). Exploring mental models of amateur paleontologists in a Community of Practice: A case study approach. International Journal of Social Media and Interactive Environments 6(1), 44-69. https://doi.org/10.1504/IJSMILE.2018. 10013530.

Macià, M., \& García, I. (2016). Informal online communities and networks as a source of teacher professional development: A review. Teaching and Teacher Education, 55(April), 291-307. https://doi.org/10.1016/j.tate.2016. 01.021.

Manca, S., \& Ranieri, M. (2016). Is Facebook still a suitable technologyenhanced environment? An updated critical review of the literature from 2012 to 2015. Journal of Computer Assisted Learning, 32(6), 503-528. https://doi.org/10.1111/jcal.12154.

Matzat, U. (2013). Do blended virtual learning communities enhance teachers' professional development more than purely virtual ones? A large scale empirical comparison. Computers \& Education, 60(1), 40-51. https://doi. org/10.1016/j.compedu.2012.08.006.

Merriam, S. B., \& Tisdell, E. J. (2009). Qualitative research: A guide to design and implementation. Jossey-Bass.

Miles, M. B., Huberman, A. M., \& Saldana, J. (2014). Qualitative data analysis: A methods sourcebook. Sage.

Miller, D. (2015). Pinterest isn't pedagogy. Texas Library Journal, 91(3), 101.

Moolenaar, N. M. (2012). A social network perspective on teacher collaboration in schools: Theory, methodology, and applications. American Journal of Education, 119(1), 7-39. https://doi.org/10.1086/667715.

Muls, J., Triquet, K., Vlieghe, J., De Backer, J. F., Zhu, C., \& Lombaerts, K. (2019). Facebook group dynamics: An ethnographic study of the teaching and learning potential for secondary school teachers. Learning, Media and Technology, 44(2), 1-18. https://doi.org/10.1080/17439884.2019.1583670.

Naseri, S. (2017). Online social network sites and social capital: A case of Facebook. International Journal of Applied Sociology, 7(1), 13-19. https://doi. org/10.5923/j.ijas.20170701.02.

Nixon, R. S., Navy, S. L., Barnett, S., Johnson, M., \& Larson, D. (2021). Pinning and planning: Five tips for using Pinterest to teach science. Science and Children, 58(3), 22-25.

Nochumson, T. C. (2019). Elementary schoolteachers' use of Twitter: Exploring the implications of learning through online social media. Professional Development in Education, 46(2), 306-323. https://doi.org/10. 1080/19415257.2019.1585382.

Opfer, V. D., Kaufman, J. H., \& Thompson, L. E. (2017). Implementation of K-12 State standards for mathematics and english language arts and literacy: Findings from the American teacher panel. Rand Corporation.

Palmquist, J. E., \& Barnes, G. V. (2015). Participation in the school orchestra and string teachers Facebook v2 group: An online community of practice. International Journal of Community Music, 8(1), 93-103. https://doi. org/10.1386/ijcm.8.1.93_1.

Ponciano, L., \& Brasileiro, F. (2014). Finding volunteers' engagement profiles in human computation for citizen science projects. Human Computation. https://doi.org/10.15346/hc.v1i2.12.

Prestridge, S. (2019). Categorising teachers' use of social media for their professional learning: A self-generating professional learning paradigm. Computers \& Education, 129(February), 143-158. https://doi.org/10. 1016/j.compedu.2018.11.003.

Prestridge, S. (2020). PLNs for educators: Why do some educators lurk while others lead? Society for Information Technology, 2020(1), 1508-1513.

Ranieri, M., Manca, S., \& Fini, A. (2012). Why (and how) do teachers engage in social networks? An exploratory study of professional use of Facebook and its implications for lifelong learning. British Journal of Educational Technology: Journal of the Council for Educational Technology, 43(5), 754-769. https://doi.org/10.1111/j.1467-8535.2012.01356.x.

Rayburn, J. (2014). Back to school with Pinterest. The ASHA Leader, July, 28-9.

Robles Moral, F. J., \& Fernández Díaz, M. (2021). Future primary school teachers' digital competence in teaching science through the use of social media. Sustainability, 13, 2816. https://doi.org/10.3390/su13052816.

Rozen, D., Askalani, M. \& Senn, T. (2012). "Staring at the sun: Identifying, understanding and influencing social media users."

Saldaña, J. (2013). The coding manual for qualitative researchers. Los Angeles: SAGE.

Sawyer, A., Dick, L., Shapiro, E., \& Wismer, T. (2019). The Top 500 mathematics pins: An analysis of elementary mathematics activities on Pinterest. Journal of Technology and Teacher Education, 27(2), 235-263.

Sawyer, A. G., \& Myers, J. (2018). Seeking comfort: How and why preservice teachers use internet resources for lesson planning. Journal of Early Childhood Teacher Education, 39(1), 16-31. https://doi.org/10.1080/ 10901027.2017.1387625.

Schroeder, S. E., Curcio, R. E., \& Lundgren, L. (2019). Expanding the learning network: How teachers use Pinterest. Journal of Research on Technology in Education. https://doi.org/10.1080/15391523.2019.1573354.

Shelton, C., \& Archambault, L. (2018). Discovering how teachers build virtual relationships and develop as professionals through online teacherpreneurship. Journal of Interactive Learning Research, 29(4), 579-602.

Sie, R. L. L., Pataraia, N., Boursinou, E., Rajagopal, K., Margaryan, A., Falconer, I., Bitter-Rijpkema, M., Littlejohn, A., \& Sloep, P. B. (2013). Goals, motivation for, and outcomes of personal learning through networks: Results of a tweetstorm. Educational Technology \& Society, 16(3), 59-75.

Smith Risser, H. (2013). Virtual induction: A novice teacher's use of Twitter to form an informal mentoring network. Teaching and Teacher Education, 35(October), 25-33. https://doi.org/10.1016/j.tate.2013.05.001.

Tracy, S. J. (2010). Qualitative quality: Eight 'big-tent' criteria for excellent qualitative research. Qualitative Inquiry, 16(10), 837-851. https://doi. org/10.1177/1077800410383121.

Trust, T. (2012). Professional Learning Networks designed for teacher learning. Journal of Digital Learning in Teacher Education, 28(4), 133-138.

Trust, T., Carpenter, J. P., \& Krutka, D. G. (2017). Moving beyond silos: Professional Learning Networks in higher education. The Internet and Higher Education, 35(October), 1-11. https://doi.org/10.1016/j.iheduc.2017. 06.001. 
Trust, T., Carpenter, J. P., \& Krutka, D. G. (2018). Leading by learning: Exploring the Professional Learning Networks of instructional leaders. Educational Media International, 55(2), 137-152. https://doi.org/10.1080/09523987. 2018.1484041.

Trust, T., Krutka, D. G., \& Carpenter, J. P. (2016). 'Together we are better': Professional Learning Networks for teachers. Computers \& Education, 102(November), 15-34. https://doi.org/10.1016/j.compedu.2016.06.007.

Vangrieken, K., Dochy, F., Raes, E., \& Kyndt, E. (2015). Teacher collaboration: A systematic review. Educational Research Review, 15(June), 17-40. https:// doi.org/10.1016/j.edurev.2015.04.002.

\section{Publisher's Note}

Springer Nature remains neutral with regard to jurisdictional claims in published maps and institutional affiliations.
Ready to submit your research? Choose BMC and benefit from:

- fast, convenient online submission

- thorough peer review by experienced researchers in your field

- rapid publication on acceptance

- support for research data, including large and complex data types

- gold Open Access which fosters wider collaboration and increased citations

- maximum visibility for your research: over 100M website views per year

At BMC, research is always in progress.

Learn more biomedcentral.com/submissions 